\title{
Specialty Grand Challenge: Negative Emission Technologies
}

\author{
Phil Renforth ${ }^{1,2 *}$ and Jennifer Wilcox ${ }^{3}$ \\ ${ }^{1}$ School of Engineering and Physical Sciences, Heriot-Watt University, Edinburgh, United Kingdom, ${ }^{2}$ Research Centre for \\ Carbon Solutions, Heriot-Watt University, Edinburgh, United Kingdom, ${ }^{3}$ Worcester Polytechnic Institute, Worcester, MA, \\ United States
}

Keywords: negative emission technologies, carbon dioxide, climate change, greenhouse gas, carbon dioxide removal (CDR)

\section{INTRODUCTION}

The United Nations painted a dire picture of humanity's future in its recent climate report (IPCC, 2018). It warned that failing to act on carbon dioxide $\left(\mathrm{CO}_{2}\right)$ emissions will lead to vanishing sea ice and melting glaciers, increased storm events, and ports and islands at risk due to rising sea levels. The report was sobering to many, but not to scientists tasked with developing solutions to climate change. We know that even if we reach previously stated emission goals, even if we replaced all coal-fired power plants with cleaner resources like wind- or sun-generated electricity, even if we found ways to otherwise reduce ongoing emissions, it would not be enough. We must also pull existing $\mathrm{CO}_{2}$ out of the atmosphere if we are to avoid the worst impacts of climate change ("Negative Emission Technologies" or NETs) (Fuss et al., 2018; Minx et al., 2018; Nemet et al., 2018). Investing in NETs now will be more affordable than a future of ever-more devastating storms, wildfires, high tides, famines, and diseases.

Under a business as usual scenario we may see a $4^{\circ} \mathrm{C}$ increase in global temperatures by 2100 , which will have a substantial pervasive impact on our planet and society. The economic cost alone for exceeding $2.5^{\circ} \mathrm{C}$ may be up to $2 \%$ of global income (IPCC, 2014a). We have already reached $1^{\circ} \mathrm{C}$ of warming (IPCC, 2018).

The scale of the challenge is daunting. The largest emission scenario used by the UN, which is our current trajectory, predicts that humanity may create $>7,000$ billion tons of $\mathrm{CO}_{2}$ over the next 80 years. If we are to avoid $2^{\circ}$ of warming, we must limit the accumulation in the atmosphere to under 500 billion tons $\mathrm{CO}_{2}$ (or $1 / 3$ of this to limit to $1.5^{\circ}$ ) (Lowe and Bernie, 2018). It is essential that we deviate away from our business as usual trajectory, and substantially limit the amount of $\mathrm{CO}_{2}$ that is created. Given that our energy infrastructure has unavoidably committed us to creating several hundred billion tons of $\mathrm{CO}_{2}$ over the next two decades (Davis and Socolow, 2014), it seems likely that not only will we need to store considerable quantities of $\mathrm{CO}_{2}$, but also remove excess $\mathrm{CO}_{2}$ from the atmosphere. The IPCC predicts that between 20 and 60 billion tons of $\mathrm{CO}_{2}$ may need to be stored underground every year (IPCC, 2014b). If so, $\mathrm{CO}_{2}$ management will become one of the largest industries, equivalent in scale to food production (HANPP, $\sim 15$ billion tons Krausmann et al., 2017), construction materials (cement, steel, aggregate $>60$ billion tons USGS, 2016; Reichl et al., 2018), and fossil fuels (coal, oil, gas, $\sim 20$ billion tons).

\section{HOW TO REMOVE GREENHOUSE GASES FROM THE ATMOSPHERE}

Renforth P and Wilcox J (2019)

Specialty Grand Challenge: Negative

Emission Technologies.

Front. Clim. 1:1

doi: 10.3389/fclim.2019.00001

NETs propose to accelerate Earth's natural processes by growing plants, increasing soil organic carbon stocks, weathering alkaline-rich rocks and increasing ocean alkalinity, and also via "synthetic forests" that draw $\mathrm{CO}_{2}$ from the air with far more efficiency than a natural forest. Unlike 
carbon capture devices in smokestacks that prevent $\mathrm{CO}_{2}$ release from power and manufacturing facilities, carbon dioxide removal focuses $\mathrm{CO}_{2}$ that is already in the air. Additionally, carbon dioxide removal helps treat $\mathrm{CO}_{2}$ emissions that are difficult to eliminate, such as those from automobiles and airplanes.

Figure 1 presents the range of NETs that have been proposed and could be considered either by the mechanism on which they remove greenhouse gases from the atmosphere (biomass growth, mineral dissolution, or directly captured) or where the greenhouse gases are ultimately stored (above/below ground biomass, marine biomass, carbonate minerals, dissolved carbonate, or physical trapping of $\mathrm{CO}_{2}$, in products). Between the mechanism of removal and the storage location there is potential for complex interaction pathways. For instance, biomass energy carbon capture and storage (BECCS) involves growing and burning biomass in a power station, and purifying/pressurizing the $\mathrm{CO}_{2}$ for injection underground. However, the $\mathrm{CO}_{2}$ produced from this process may also be reacted with silicate minerals ("mineral carbonation") to store the $\mathrm{CO}_{2}$ in carbonates or used to accelerate the weathering of limestone.

Most of NETs research to date focuses on removing $\mathrm{CO}_{2}$ from the atmosphere (other greenhouse gases, e.g., methane

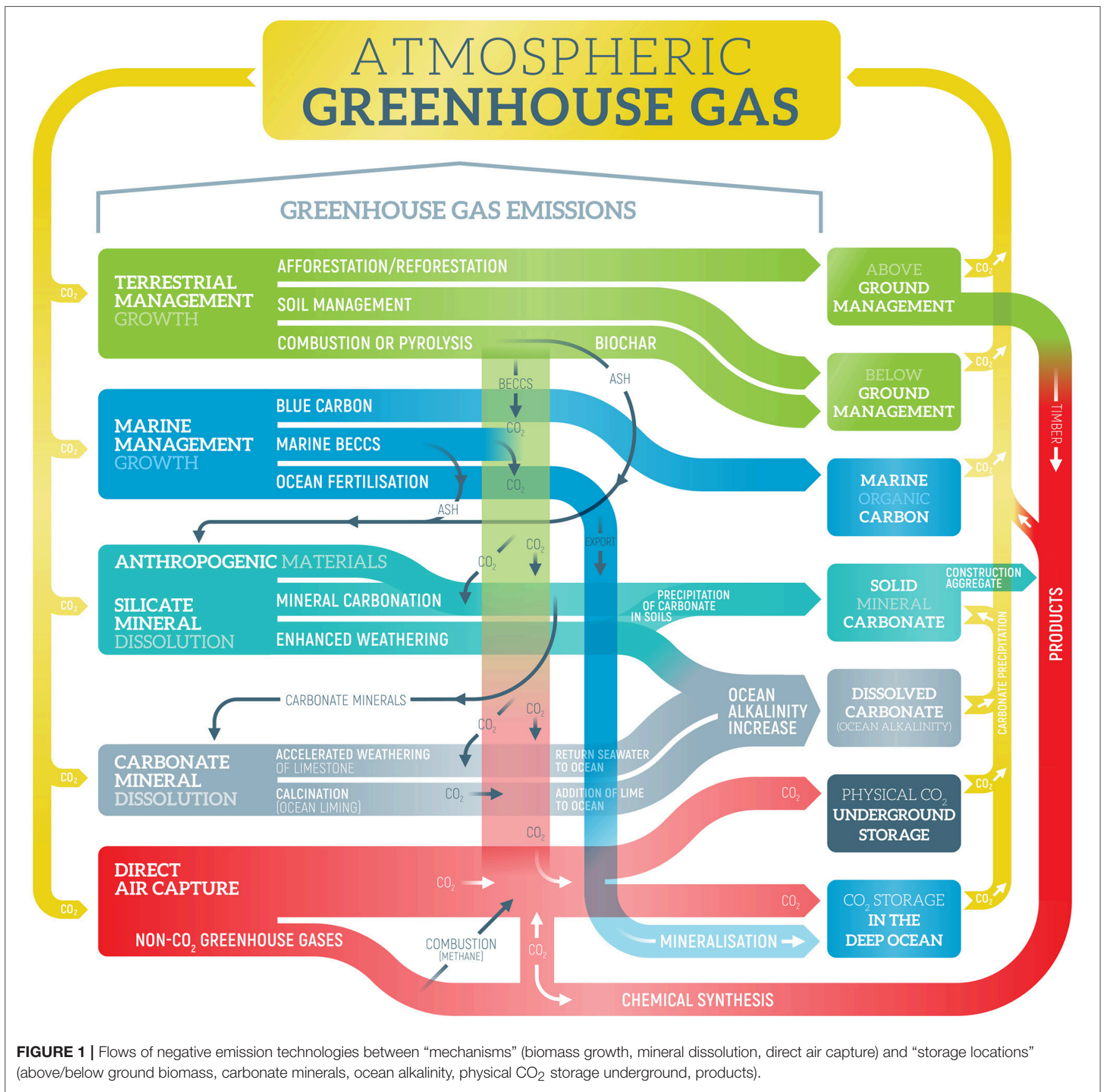


Boucher and Folberth, 2010, should also be explored), and generally as bespoke isolated technologies. There is a need to explore NETs that not only interact with each other, but with the wider socio-economic and environmental system in which they operate.

While some of these proposals may be sensible to pursue for being relatively inexpensive or come with substantial social or environmental benefits (e.g., afforestation or soil organic carbon management), they may be limited in the scale at which the carbon dioxide removal can be deployed and sustained. Other proposals may be scalable (Direct Aire Capture or Mineral Carbonation), but they are currently at early stages of development and may prove to be relatively expensive.

\section{EMISSIONS REDUCTION AND NETS}

Any technology or system operating at a global scale will be limited either geophysically by the Earth's planetary boundaries, by what might be technically or financially possible, or by social or politically acceptability. None of the negative emission technologies can be singularly scaled-up to deal with all of humanities $\mathrm{CO}_{2}$ emissions. Even so, there is a possibility that developing negative emissions will impede emission reduction activities (Markusson et al., 2018), which is a significant risk if policy were created without these limitations in mind. Clearly, NETs have a role in displacing some of the emissions from hard to reduce sectors, yet it remains poorly understood how much of global emissions could or should be mitigated by NETs.

The 2000 Royal Commission on Environmental Pollution (Royal Commission on Environmental Pollution, 2000) called for a 60\% reduction in UK emissions from their 1998 level by 2050 , which was later increased to $80 \%$ and enshrined in UK law through the Climate Change Act (UK Government, 2008). In the context of the targets contained in the Kyoto Protocol ( $-8 \%$ by $2010,-20 \%$ by 2020 ), this was a relatively bold target. Other similar targets have been proposed, and with varied levels of commitment from national governments (Rogelj et al., 2016). However, these emission targets have strongly influenced how we view emission reduction technologies. Under these emission reduction regimes, the IEA Energy Technology Perspectives (IEA, 2006), presented marginal abatement costs of $<\$ 50$ per ton of $\mathrm{CO}_{2}$ for power generation, and highlight some opportunities where reducing $\mathrm{CO}_{2}$ emissions may save money. The latest IPCC report on limiting warming to $<1.5^{\circ} \mathrm{C}$ makes it clear that not only do we need to reduce emissions to zero by mid-century but promote a net removal of $\mathrm{CO}_{2}$ from the atmosphere thereafter. Under these stringent emission targets, integrative assessment models predict the cost of $\mathrm{CO}_{2}$ abatement to increase to well over $\$ 100 / \mathrm{t}$ by mid-century, and to over $\$ 1000 / \mathrm{t}$ by 2100 . It is this expensive abatement tail that may control the cost of preventing climate change. It is for this reason, that we are now considering relatively expensive proposals for removing $\mathrm{CO}_{2}$ from the atmosphere, which have a unique ability of capping the cost curve (Keith et al., 2006).

One option to offset costs is the conversion of removed $\mathrm{CO}_{2}$ into a marketable product. Several important industrial commodities take $\mathrm{CO}_{2}$ as a source material to make new plastics or other chemicals. However, $\mathrm{CO}_{2}$ conversion often results in the inevitable re-emission of $\mathrm{CO}_{2}$ back into the atmosphere. Here, the result is not negative emissions, but rather, at best, a stabilization of atmospheric $\mathrm{CO}_{2}$ levels. It is important to note that substituting a product with one that uses $\mathrm{CO}_{2}$ as a feedstock could also displace emissions from production of the original raw materials, but again, this is emissions reduction rather than negative emissions. Other industries like cement, aluminum, steel, lime, caustics, mining, rock aggregate production, desalination, and paper production, may contain "hidden" opportunities for negative emissions, that are only realized once their emissions are curtailed.

\section{FUTURE RESEARCH}

Through research and support for pilot- and demonstration-scale projects, we will learn more about $\mathrm{CO}_{2}$ removal and ultimately find ways to make permanent removal and negative emissions processes cost-effective. Both the Royal Society (UK) and the National Academy of Sciences, Engineering and Medicine (US) have called for investment in research and development (National Academies of Sciences Engineering and Medicine, 2018; The Royal Society, 2018). Investing in these early-stage technologies today may also lead to parallel technological advances as seen with computers, communications systems, solar cells, aircraft, and cars. Some NETs could have trans-boundary environmental, social, and economic impacts, which may be benign or even positive in niche applications. However, when operating at a global scale the impacts may be prohibitive. Research is required for each process (and a portfolio of approaches) to understand if, or where, this threshold of scale exists. While reducing emissions should be a priority, it is morally questionable to focus on relatively cheaper emissions reduction without any consideration of NETs. This merely shifts the responsibility, and cost, onto the backs of future generations.

The Carbon Clock produced by the MCC in Berlin predicts that we have 9 years before the $\mathrm{CO}_{2}$ levels in the atmosphere are enough to warm the planet by $1.5^{\circ} \mathrm{C}$ (MCC, 2019), a target that is currently not possible to achieve unless emissions are considerably reduced, and the feasibility of NETs determined.

\section{AUTHOR CONTRIBUTIONS}

All authors listed have made a substantial, direct and intellectual contribution to the work, and approved it for publication.

\section{FUNDING}

PR would like to acknowledge funding from NERC, the Engineering and Physical Sciences Research Council (EPSRC), Economic and Social Research Council (ESRC), and the Department for Business, Energy and Industrial Strategy (BEIS) through the UK's Greenhouse Gas Removal Programme under grants NE/P019943/1 and NE/P019730/1. 


\section{REFERENCES}

Boucher, O., and Folberth, G. A. (2010). New directions: atmospheric methane removal as a way to mitigate climate change? Atmospher. Environ. 44, 3343-3345. doi: 10.1016/j.atmosenv.2010.04.032

Davis, S. J., and Socolow, R. H. (2014). Commitment accounting of CO 2 emissions. Environ. Res. Lett. 9:084018. doi: 10.1088/1748-9326/9/8/084018

Fuss, S., Lamb, W. F., Callaghan, M. W., Hilaire, J., Creutzig, F., Amann, T., et al. (2018). Negative emissions-Part 2: costs, potentials and side effects. Environ. Res. Lett. 13:063002. doi: 10.1088/1748-9326/aabf9f

IEA (2006). Energy Technology Perspectives 2006. International Energy Agency. doi: $10.1787 / 9789264109834$-en

IPCC (2014a). Climate Change 2014: Synthesis Report. Contribution of Working Groups I, II and III to the Fifth Assessment Report of the Intergovernmental Panel on Climate Change, eds Core Writing Team, R. K. Pachauri, and L. A. Meyer. Geneva: IPCC. $151 \mathrm{p}$.

IPCC (2014b). Climate Change 2014: Mitigation of Climate Change. Contribution of Working Group III to the Fifth Assessment Report of the Intergovernmental Panel on Climate Change, eds O. Edenhofer, R. Pichs-Madruga, Y. Sokona, E. Farahani, S. Kadner, K. Seyboth, A. Adler, I. Baum, S. Brunner, P. Eickemeier, B. Kriemann, J. Savolainen, S. Schlömer, C. von Stechow, T. Zwickel, and J. C. Minx. New York, NY: Cambridge University Press, Cambridge.

IPCC (2018). Summary for Policymakers. Global Warming of $1.5^{\circ} \mathrm{C}$. An IPCC Special Report on the Impacts of Global Warming of $1.5^{\circ} \mathrm{C}$ Above Pre-Industrial Levels and Related Global Greenhouse Gas Emission Pathways, in the Context of Strengthening the Global Response to the Threat of Climate Change, Sustainable Development, and Efforts to Eradicate Poverty, eds V. Masson-Delmotte, P. Zhai, H. O. Pörtner, D. Roberts, J. Skea, P. R. Shukla, A. Pirani, W. MoufoumaOkia, C. Péan, R. Pidcock, S. Connors, J. B. R. Matthews, Y. Chen, X. Zhou, M. I. Gomis, E. Lonnoy, T. Maycock, M. Tignor, and T. Waterfield (Geneva: World Meteorological Organization), 32.

Keith, D. W., Ha-Duong, M., and Stolaroff, J. K. (2006). Climate strategy with CO 2 capture from the air. Climatic Change 74, 17-45. doi: 10.1007/s10584-005-9026-x

Krausmann, F., Wiedenhofer, D., Lauk, C., Haas, W., Tanikawa, H., Fishman, T., et al. (2017). Global socioeconomic material stocks rise 23-fold over the 20th century and require half of annual resource use. Proc. Natl. Acad. Sci. U.S.A. 114, 1880-1885. doi: 10.1073/pnas.1613773114

Lowe, J. A., and Bernie, D. (2018). The impact of Earth system feedbacks on carbon budgets and climate response. Philos. Trans. R. Soc. A Math. Phys. and Eng. Sci. 376:20170263. doi: 10.1098/rsta.2017.0263
Markusson, N., McLaren, D., and Tyfield, D. (2018). Towards a cultural political economy of mitigation deterrence by negative emissions technologies (NETs). Glob. Sust. 1:e10. doi: 10.1017/sus.2018.10

MCC (2019). Mercator Research Institute on Global Commons and Climate Change - Carbon Calculator. Available online at: https://www.mcc-berlin.net/en/research/co2-budget.html (accessed February 7, 2019).

Minx, J. C., Lamb, W. F., Callaghan, M. W., Fuss, S., Hilaire, J., Creutzig, F., et al. (2018). Negative emissions-Part 1: research landscape and synthesis. Environ. Res. Lett. 13:063001. doi: 10.1088/1748-9326/aabf9b

National Academies of Sciences Engineering and Medicine (2018). Negative Emissions Technologies and Reliable Sequestration: A Research Agenda. Washington, DC: National Academies of Sciences Engineering and Medicine. doi: $10.17226 / 25259$

Nemet, G. F., Callaghan, M. W., Creutzig, F., Fuss, S., Hartmann, J., Hilaire, J., et al. (2018). Negative emissions-Part 3: innovation and upscaling. Environ. Res. Lett. 13:063003. doi: 10.1088/1748-9326/aabff4

Reichl, C., Schatz, M., and Zsak, G. (2018). World Mining Data. Vienna: International Organizing Committee for the World Mining Congresses.

Rogelj, J., den Elzen, M., Höhne, N., Fransen, T., Fekete, H., Winkler, H., et al. (2016). Paris Agreement climate proposals need a boost to keep warming well below $2^{\circ} \mathrm{C}$. Nature 534, 631-639. doi: 10.1038/nature 18307

Royal Commission on Environmental Pollution (2000). Energy - The Changing Climate. Royal Commission on Environmental Pollution.

The Royal Society (2018). Greenhouse Gas Removal. The Royal Society/Royal Academy of Engineering.

UK Government (2008). Climate Change Act 2008. UK Government.

USGS (2016). USGS Minerals Yearbook. Reston, VA: U.S. Department of the Interior and U.S. Geological Survey.

Conflict of Interest Statement: The authors declare that the research was conducted in the absence of any commercial or financial relationships that could be construed as a potential conflict of interest.

Copyright (c) 2019 Renforth and Wilcox. This is an open-access article distributed under the terms of the Creative Commons Attribution License (CC BY). The use, distribution or reproduction in other forums is permitted, provided the original author(s) and the copyright owner(s) are credited and that the original publication in this journal is cited, in accordance with accepted academic practice. No use, distribution or reproduction is permitted which does not comply with these terms. 